\title{
Tingkat Instabilitas Komoditi Ekspor Nonmigas di Indonesia Periode 2007Q1-2015Q4
}

\section{(The Great Instability of Non Oil and Gas Export Commodities in Indonesia Period 2007Q1-2015Q4)}

\author{
Shofiyya Farras Setyawan, Lilis Yuliati, Fajar Wahyu Prianto ${ }^{1}$ \\ Jurusan Ilmu Ekonomi dan Studi Pembangunan, Fakultas Ekonomi dan Bisnis, Universitas Jember (UNEJ) \\ Jln. Kalimantan 37, Jember 68121 \\ E-mail: lilisyuliati.feb@unej.ac.id
}

\begin{abstract}
Abstrak
Tujuan penelitian ini adalah untuk mengetahui tingkat nilai instabilitas ekspor nonmigas di Indonesia dan untuk mengetahui faktor dominan yang mempengaruhi pergerakan tingkat instabilitas ekspor nonmigas di Indonesia. Jenis data yang digunakan dalam penelitian ini adalah data sekunder yang bersumber dari BI dan instansi yang terkait. Alat analisis yang digunakan dalam penelitian ini adalah indeks instabilitas ekspor dengan data timeseries. Objek penelitian ini adalah nilai, volume dan harga ekspor nonmigas di Indonesia periode 2007Q1-2015Q4. Hasil dari penelitian yang dilakukan diketahui bahwa pergerakan nilai ekspor nonmigas di Indonesia relatif stabil atau memiliki tingkat instabilitas yang rendah dan faktor dominan yang mempengaruhi adalah volume ekspor.
\end{abstract}

Kata Kunci: Instabilitas ekspor, indeks instabilitas, Nonmigas, ekspor

\begin{abstract}
The purpose of this study was to assess the value of non-oil export instability in Indonesia and to determine the dominant factor affecting the movement of the level of instability in Indonesia's non-oil exports. The data used in this research is secondary data obtained from the central bank and the relevant agencies. The analytical tool used in this research is the index of instability of exports to the data time series. The objects of this study are value, volume and price of non-oil exports in Indonesia 2007Q12015Q4 period. The results of this study is the movement of the value of non-oil exports in Indonesia are relatively stable or have a low level of instability and the dominant affecting factor is the volume of exports.
\end{abstract}

Keywords: Instability of exports, instability indexes, non-oil, export

\section{Pendahuluan}

Keberhasilan suatu negara dalam meningkatkan pertumbuhan perekonomian dapat dilihat dari indikator pembangunan untuk meningkatkan kesejahteraan masyarakatnya yang didukung oleh infrastruktur dalam suatu kegiatan perekonomian negara. Indonesia merupakan salah satu negara berkembang (emerging market) yang sedang melakukan kegiatan perekonomian salah satunya dalam bentuk pembangunan (Agustina dan Reny, 2014). Perkembangan perekonomian Indonesia yang semakin terintegrasi dengan perekonomian dunia membawa perekonomian Indonesia dalam sistem perekonomian terbuka kecil (Febriyenti dkk., 2013). Salah satu kegiatan dalam perekonomian terbuka yaitu melalui jalur perdagangan internasional yang terdiri dari impor dan ekspor baik barang dan jasa yang dilakukan antar suatu negara dengan negara lain (Mankiw, 2006: 114).

Kegiatan ekspor dalam perdagangan internasional terdiri dari dua sektor yaitu sektor migas dan nonmigas. Melalui kedua sektor tersebut, suatu negara dapat melakukan perdagangan dengan cara spesialisasi. Terdapat manfaat langsung yang dihasilkan ketika suatu negara melakukan spesialisasi produk barang tertentu, negara tersebut dapat mengekspor komoditi untuk dipertukarkan dengan produk yang di produksi oleh negara lain. Kegiatan spesialisasi ekspor akan memberikan keuntungan bagi negara dan dapat meningkatkan pendapatan nasional yang berdampak pada output dan laju pertumbuhan ekonomi (Jhingan, 2003: 447-448). Namun dampak negatif adanya spesialisasi dapat mendorong terjadinya fokus ketergantungan terhadap sebuah komoditas tertentu yang dapat diunggulkan.

Pergerakan ekspor Indonesia lebih didominasi oleh sektor nonmigas sebagai penopang utama kegiatan ekspor di Indonesia. Pergerakan tingkat nilai ekspor dari tahun ke tahun memiliki titik yang berbeda, hal ini dapat menyebabkan ekspor Indonesia rentan terhadap instabilitas ekspor. Pada umumnya instabilitas ekspor telah menjadi permasalahan hampir pada semua negara. Faktor yang menjadi penyebab instabilitas ekspor diantaranya ketergantungan terhadap beberapa negara tujuan dan ketergantungan sebagai negara berkembang terhadap komoditi primer dan komoditi tertentu yang mengakibatkan penghambatan terhadap pertumbuhan perekonomian, mengurangi pertumbuhan investasi, kerugian pembangunan dan mengurangi perkembangan ekspor di masa yang akan datang (Hafizrianda, 1998). Hal tersebut dapat membawa dampak buruk dari dua sudut pandang ekonomi. Pertama, dari ekonomi mikro yang dapat menimbulkan ketidakpastian di sektor ekspor yang mengakibatkan eksportir melakukan spekulaif dalam perdagangan. Hal ini terjadi karena negara pengimpor akan cendrung memilih negara yang memiliki keadaan ekspor yang lebih stabil, begitu juga dengan para investor. Kedua, dilihat dari ekonomi makro, instabilitas ekspor akan mempengaruhi keadaan komoditi

1 Penulis Korespondensi 
secara langsung pada variabel agregat yang akan berdampak pada pendapatan, impor bahan baku dan pengambilan keputusan dalam melakukan pembangunan (Pan A dan Jeffrey, 1976: 337-338). Pada umumnya keadaan instabilitas ekspor banyak dialami oleh sebagian besar negara di dunia termasuk Indonesia. Artikel ini mengkaji tingkat instabilitas komoditi ekspor nonmigas di Indonesia.

\section{Metode}

\section{Desain Penelitian}

Penelitian ini menggunakan metode indeks instabilitas ekspor yang bertujuan untuk menjelaskan pergerakan tingkat instabilitas ekspor dan faktor dominan yang mempengaruhi. Variabel yang digunakan dalam penelitian adalah nilai, volume dan harga ekspor nonmigas di Indonesia.

\section{Jenis dan Sumber Data}

Jenis data yang digunakan dalam penelitian ini adalah data sekunder yang berbentuk data timeseries sebagai alat pengolahan data dengan menggunakan Program excel. Sumber data yang digunakan dalam penelitian ini diperoleh dari situs resmi Bank Indonesia.

\section{Populasi dan Sampel}

Populasi data penelitian mencakup semua komoditas ekspor non migas. Sampel waktu pada periode tahun 2007Q12015Q4, karena pada 2007 dimulainya perhatian khusus Menteri Perdagangan pada kinerja ekspor khususnya sektor nonmigas. Selain itu peneliti juga ingin melihat jangka waktu satu tahun sebelum terjadinya krisis subprime mortagage pada tahun 2008, dan pada tahun 2014 mulai diberlakukannya UU pembatasan ekspor minerba dan ekspor komoditi dalam bentuk mentah.

\section{Metode Analisis Data}

Untuk mengetahui tingkat instabilitas ekpor nonmigas di Indonesia digunakan analisis indeks instabilitas ekspor. Pertama, dicari trend waktu menggunakan regresi terkecil melalui persamaan regresi menurut Hafizrianda (1998):

$$
\begin{aligned}
& =a_{o}+b_{o} t \\
& =a_{1}+b_{1} t \\
& =a_{2}+b_{2} t
\end{aligned}
$$

Dimana, dan ${ }_{t}$ adalah nilai, volume dan harga ekspor pada tahun $\mathrm{t}$, $\mathrm{t}$ adalah variabel waktu, sedangkan $a_{0}$ dan $b_{0}$ adalah parameter konstan. Dari persamaan diatas, langkah untuk memperoleh nilai $U_{t}$ adalah:

$$
\begin{aligned}
\mathrm{U}_{\mathrm{t}} & =\mathrm{R}_{\mathrm{t}}- \\
\mathrm{U}_{\mathrm{t}} & =\mathrm{q}_{\mathrm{t}}- \\
\mathrm{U}_{\mathrm{t}} & =\mathrm{p}_{\mathrm{t}}-
\end{aligned}
$$

Dimana $R_{t}$ adalah nilai pada tahun $t, q_{t}$ adalah volume pada tahun $t$, dan $p_{t}$ adalah harga pada tahun $t$. Dari persamaan diatas selanjutnya ditentukan tingkat instabilitas yang mengadopsi dari model Wong (1984):

$I_{R}=$

$I_{q}=$

$I_{p}=$

Dimana $I_{R}$ adalah indeks instabilitas nilai ekspor, $I_{q}$ adalah indeks instabilitas volume ekspor dan $I_{P}$ adalah indeks instabilitas harga ekspor, $U_{t}$ adalah residu yang dihitung berdasarkan persamaan 1, 2, 3, sedangkanadalah rata-rata nilai ekspor, volume ekspor dan harga ekspor pada masingmasing komoditi, $\mathrm{t}$ adalah waktu dan $\mathrm{T}$ adalah jumlah tahun pengamatan. Langkah selanjutnya, untuk mengetahui stabil tidaknya pergerakan nilai ekspor dengan mencari rata-rata indeks instabilitas nilai ekspor. Jika IR $<$ rata rata indeks nilai ekspor, berarti ekspor dalam keadaan stabil. Jika IR $>$ rata rata indeks nilai ekspor, berarti ekspor dalam keadaan instabilitas atau tidak stabil. Sedangkan untuk mengetahui faktor dominan yang mempengaruhi komoditi ekspor dengan cara IP/IQ, apabila IP/IQ $<1$ berarti instabilitas ekspor nonmigas di Indonesia lebih disebabkan oleh volume. Sedangkan apabila IP/IQ $>1$ berarti instabilitas ekspor nonmigas di Indonesia lebih dipengaruhi oleh harga.

\section{Hasil dan Pembahasan}

\section{Hasil}

Berdasarkan hasil analisis indeks instabilitas ekspor menggunakan data timeseries, dapat dijelaskan sebagai berikut :

a) Rata-rata nilai indeks instabilitas komoditi ekspor nonmigas di Indonesia mencapai angka 0,341. Artinya nilai tengah yang menjadi batas indikator indeks instabilitas ekspor adalah 0,341. Beberapa komoditi memiliki indeks nilai ekspor diatas 0,341 , dan sebagian komoditi memiliki indeks dibawah 0,341. Hal ini menunjukan bahwa beberapa komoditi berada pada posisi stabil dan beberapa komoditi memiliki posisi yang tidakstabil. Namun secara keseluruhan komoditi ekspor nonmigas di Indonesia berada dibawah angka 0,341 yang berarti menunjukan ekspor komoditi nonmigas di Indonesia relatif stabil.

b) Periode yang memiliki tingkat instabilitas tertinggi secara total ekspor adalah tahun 2008 sebesar 0,083817 . Periode yang memiliki tingkat instabilitas pada sektor pertanian adalah tahun 2010 sebesar 0,162132. Periode yang memiliki tingkat instabilitas tertinggi pada sektor industri adalah tahun 2008 sebesar 0,092054 dan Periode yang memiliki tingkat instabilitas ekspor tertinggi pada sektor pertambangan adalah 2009 sebesar 0,180179.

c) Pada sektor pertanian, komoditi yang memiliki indeks instabilitas tertinggi adalah karet. Pada sektor perindustrian komoditi yang memiliki tingkat instabilitas tertinggi adalah barang dan logam mulia. Sedangkan pada sektor pertambangan, komoditi yang memiliki tingkat instabilitas tertinggi adalah bauksit.

d) Nilai pembagian antara IP/IQ pada komoditi ekspor nonmigas menunjukan, terdapat beberapa komoditi yang memiliki tingkat instabilitas ekspor dibawah satu yang berarti pergerakan ekspor lebih dipengaruhi oleh volume. Selain itu terdapat beberapa komoditi yang menunjukan hasil diatas satu, yang berarti pergerakan nilai ekspor lebih dipengaruhi oleh harga. Namun secara keseluruhan faktor dominan yang paling banyak mempengaruhi tingkat instabilitas ekspor nonmigas di Indonesia adalah volume, hal ini dikarenakan hasil pembagian antara indeks harga dan volume lebih kecil daripada 1. 


\section{Pembahasan}

Penelitian ini menjelaskan tentang pergerakan tingkat instabilitas ekspor nonmigas di Indonesia dan faktor dominan yang mempengaruhi pergerakan. Berdasarkan hasil penelitian dapat diketahui bahwa:

1. Tingkat istabilitas ekspor menunjukan hasil yang relatif stabil. Hal ini dikarenakan banyaknya komoditas yang memiliki indeks nilai dibawah 0,341 .

Secara komoditas, pergerakan ekspor nonmigas relatif stabil berdasarkan hasil penelitian secara statistik. Hanya pada tahun tertentu yang memiliki tingkat instabilitas tertinggi pada komoditi ekspor nonmigas. Pada tahun 2008 nilai ekspor nonmigas secara keseluruhan memiliki tingkat instabilitas tertinggi. Hal ini diakaibatkan oleh adanya krisis subprime mortagage yang terjadi di Amerika. Krisis tersebut berdampak pada penurunan harga dan volume pada komoditas ekspor non migas. Beberapa sektor yang terkena dampak krisis adalah sektor industri dan pertambangan (Bank Indonesia, 2008). Selanjutnya tahun yang memiliki tingkat instabilitas tertinggi pada sektor pertanian adalah tahun 2010 . Hal ini dikarenakan pada tahun 2010 permintaan dunia tumbuh semakin tinggi namun dari sisi persedian komoditas mengalami suatu kendala karena adanya faktor cuaca yang ekstream. Akibatnya harga pada beberapa komoditas utama sektor pertanian mengalami kenaikan yang tajam. Sehingga dari kejadian ini ekspor pada sektor pertanian walaupun tetap tumbuh positif namun tidak terlalu berkontribusi pada peningkatan ekspor di Indonesia pada tahun tersebut (Bank Indonesia, 2010). Pada sektor industri, tahun yang memiliki instabilitas tertinggi adalah tahun 2008 sedangkan pada sektor pertambangan tahun yang memiliki instabilitas tertinggi adalah tahun 2009. kedua tahun tersebut menjadi nilai tertinggi dalam tingkat instabilitas ekspor nonmigas disebabkan oleh faktor yang sama yakni krisis subrime mortagage (Bank Indonesia, 2009).

2. Nilai instabilitas tertinggi pada sektor pertanian adalah komoditi karet, yang pergerakannya lebih dipengaruhi oleh harga ekspor.

Hal ini sesuai dengan Bank Indonesia (2007) yang menyatakan ketidakstabilan ekspor karet lebih dipengaruhi oleh harga yang disebabkan oleh kondisi permintaan karet dan pasokan dunia. Indonesia merupakan negara kedua penghasil ekspor terbesar karet alam setelah Thailand, dan penghasil ketiga terbesar didunia adalah Malaysia. Selain itu menurut Bank Indonesia (2008) juga menyatakan harga karet terus meningkat karena, permintaan terbesar datang dari Cina, hal ini terjadi dikarenakan ekspor karet dari Thailand dan Malaysia yang terhambat sehingga semua permintaan datang ke Negara Indonesia. Terhambatnya ekspor karet dari Negara Malaysia dan Thailand disebabkan oleh pengaruh musim gugur yang dialami oleh kedua negara. Peningkatan harga karet terus terjadi hingga tahun 2010.

Menurut teori kestabilan harga memiliki pengaruh yang sangat penting dalam menentukan ketidakstabilan ekspor pada kegiatan ekspor (Herrmann, 1983). Sehingga untuk menangani ketidakstabilan yang disebabkan oleh ekspor karet, ketiga negara penghasil ekspor utama didunia berusaha untuk mengendalikan harga dengan mengatur volume karet sehingga dapat mengantisipasi kelebihan pasokan dipasar dunia terutama pada saat musim panen. Antisipasi ini terus berlanjut, pada tahun 2009 volume ekspor terus ditekan hingga diberlakukannya kerjasama antara Gabungan Pengusaha Karet Indonesia (GAPKINDO) dengan International Tripartite Rubber Coincil (ITRC) untuk mengurangi volume ekspor. Pengurangan dilakukan dengan peremajaan kembali pohon karet dan penebangan pada pohon karet yang sudah tua dan tidak produktif (Bank Indonesia, 2009). Dari beberapa pemaparan tersebut maka dapat dilihat bahwa ketidakstabilan ekspor lebih dipengaruhi oleh harga karena volume cenderung bisa memenuhi penawaran ekspor, bahkan permintaan melebihi penawaran yang menyebabkan ketidakstabilan harga terjadi.

3. Nilai instabilitas tertinggi pada sektor industri adalah komoditi barang dan logam mulia, yang pergerakannya lebih dipengaruhi oleh harga ekspor.

Ketidakstabilan komoditas barang dan logam mulia lebih dipengaruhi oleh harga, hal ini dikarenakan menurut kementrian perdagangan (2012) barang logam mulia yang bersifat langkah sehingga memiliki cadangan atau penawaran yang rendah sedangkan permintaan yang diminta para konsumen lebih tinggi. Logam mulia terutama perak tidak hanya berupa perhiasan tetapi juga sebagai sarana kesehatan bagi dunia kedokteran, kerajinan, peralatan elektronik dll sehingga banyak dibutuhkan oleh industri-industri besar. Harga juga dapat lebih berfluktuasi ketika suatu penambang menemukan lokasi dan pembaruan teknologi yang lebih efisien. Menurut kementrian perdagangan (2012) juga menyatakan bahwa barang dan logam mulia memiliki peran pendamping bagi nilai tukar. Sehingga ketika nilai tukar tidak stabil maka akan mempengaruhi penawaran dan permintaan yang mengakibatkan harga barang dan logam mulia berfluktuasi. Pada dasarnya pergerakan harga logam mulia lebih dipengaruhi oleh faktor fundamental yang diantaranya meliputi kondisi finansial terkini, inflasi dan konflik politik.

4. Nilai instabilitas tertinggi pada sektor pertambangan adalah komoditi bauksit, yang pergerakannya lebih dipengaruhi oleh harga ekspor.

Ketidakstabilan ekspor komoditas bauksit lebih tinggi dibandingkan komoditas lain karena ekspor komoditas dalam bentuk bahan mentah sehingga memiliki nilai jual yang lebih rendah, padahal diketahui bauksit memiliki keunggulan yang lebih tinggi jika diekspor dalam bentuk barang jadi seperti alumina yang selanjutnya dijadikan alumunium, dan sisanya digunakan sebagai pembuatan bata tahan panas, kramik, dan bahan penggosok (Kementrian Energi dan Sumberdaya Mineral, 2012).

Ekspor komoditas bauksit dalam bentuk mentah atau Raw Material memiliki nilai jual yang rendah dibandingkan negara yang mengekspor bauksit dalam bentuk bahan jadi atau setengah jadi. Padahal diketahui bahwa Indonesia merupakan penghasil bauksit terbesar di dunia. Pengiriman bauksit dalam bentuk bahan mentah terus ditingkat sebelum tahun 2014. Hal ini dikarenakan adanya peraturan yang dibuat berdasarkan UU No. 23 Tahun 2010 tentang pelaksanaan kegiatan usaha pertambangan mineral termasuk bauksit didalamnya yang mewajibkan bagi semua perusahaan tambang untuk mengolah barang mentah tambang sebelum diekspor. Peraturan ini diterapkan paling lambat pada tahun 2014. Sehingga para 
penambang lebih gencar melakukan pengiriman barang dalam bentuk mentah sebelum tahun 2014 (Kementrian eneregi dan sumberdaya mineral, 2012). Akibatnya permintaan semakin meningkat yang mengakibatkan berfluktuasinya harga baik nasional maupun internasional. Permintaan yang semakin meningkat membuat harga juga ikut meningkat. Selain itu faktor lain yang muncul adalah banyak perusahaan pertambangan yang mengikat kontrak dengan negara maju sehingga Indonesia harus menuruti semua peraturan yang tertera dalam kontrak sesuai perjanjian yang mengakibatkan Indonesia tidak dapat mengendalikan harga, dimana ketika harga harusnya tinggi karena permintaan meningkat namun karena kontrak yang ditetapkan, harga tetap dalam keadaan rendah (Kementrian Perdagangan, 2013). Hal ini yang mengakibatkan ketidakstabilan lebih dipengaruhi oleh harga.

5. Faktor dominan yang mempengaruhi pergerakan nilai ekspor adalah volume. Hal ini dikarenakan hasil pembagian indeks harga dan volume lebih kecil daripada 1 memperoleh jumlah yang lebih banyak dari pada hasil pembagian indeks harga dan volume lebih besar dari 1 .

Hasil penelitian ini sesuai dengan penelitian sebelumnya yang dilakukan oleh Herrmann (1983) yang menyatakan bahwa terdapat beberapa negara yang pergerakan instabilitas ekspornya dipengaruhi oleh harga, dan beberapa negara lainnya dipengaruhi oleh volume. Hermann (1983) menyatakan pentingnya melakukan pengendalian harga agar terus stabil. Namun jika pergerakan atau fluktuasi disebabkan oleh volume ekspor hal ini menunjukan bahwa Indonesia tidak bisa menjanjikan kepada pengimpor atas barang yang tersedia karena fluktuasi volume yang ada, selain itu Indonesia bukan sebagai salah satu negara yang dapat mempengaruhi harga. Hal ini dikarenakan Indonesia bukan satu-satunya negara pengekspor pada komoditi tertentu, atau akibat negara lain yang banyak meniru produk ekspor Indonesia sehingga Indonesia bukan lagi satu-satunya produsen yang mengirim produk ekspor tersebut.

\section{Simpulan}

Tingkat instabilitas nilai ekspor nonmigas di Indonesia menunjukan indeks yang kecil, hal ini menunjukan hasil yang relatif stabil. Faktor dominan yang mempengaruhi pergerakan nilai komoditi ekspor nonmigas di Indonesia adalah volume ekspor yang berarti ekspor nonmigas relatif inelastis yang berarti dibutuhkan waktu untuk dapat memenuhi permintaan ekspor nonmigas tersebut.

Indonesia perlu menyusun kembali strategi kebijakan sekaligus menerapkan kebijakan yang sudah ada agar kebijakan yang sudah dibuat benar-benar diterapkan dalam kegiatan ekspor untuk mendorong terciptanya pemanfaatan yang efisien pada kegiatan ekspor, khususnya pada ketersediaan fasilitas teknologi dan kemampuan, sehingga Indonesia dapat memenuhi semua permintaan pengimpor dan dapat menjanjikan barang yang ada. Selain itu kebijakan yang diambil pada dasarnya harus mengoptimalkan pengolahan bahan baku dan sumberdaya melalui pengelolaan, pengolahan dan pemanfaatan barang primer menjadi barang jadi. Sehingga Indonesia tidak hanya memberikan peluang besar terhadap negara lain tetapi juga membuka peluang besar bagi Indonesia untuk mendapatkan pendapatan negara yang lebih besar dan optimal. Beberapa cara yang dapat dilakukan diantaranya sebagai berikut:

1. Perlu adanya perdagangan komoditas berjangka. Perdagangan komoditas berjangka ini untuk menghindari adanya fluktuasi volume ekspor nonmigas yang dapat dilakukan dengan penawaran hasil komoditi ekspor nonmigas melalui pemesanan jauh-jauh hari sehingga Indonesia dapat mempersiapkan komoditas yang diminta oleh negara pengimpor.

2. Untuk menjaga tingkat stabilitas atas volume dari suatu komoditas ekspor diperlukan adanya kebijakan preventif seperti aturan atau batasan wajib ekspor komoditas, hal tersebut ditujukan ketika komoditas pada tahun tertentu mengalami penurunan masih dapat diatas dengan adanya persediaan atas adanya kelebihan komoditas pada periode sebelumnya.

3. Deversifikasi produk, kebijakan perdagangan diarahkan pengembangan berbagai produk, sehingga tidak akan terjadi ketergantungan pada satu komoditas tertentu. Selain itu pemerintah juga memfasilitasi tekhnologi dan kebutuhan dalam kegiatan ekspor untuk meminimalisir adanya perdagangan atau ekspor bahan mentah.

4. Melakukan peningkatan fasilitas dan iklim usaha perdagangan dengan dilakukan promosi secara online untuk mempercepat kegitan promosi Indonesia dan mempermudah alur informasi melalui media online.

\section{Referensi}

Agustina dan Reny. 2014. Pengaruh Ekspor, Impor, Nilai Tukar Rupiah, dan Tingkat Inflasi terhadap Cadangan Devisa Indonesia. Wira Ekonomi Mikrosil, 4(2): 61-70.

Bank Indonesia. 2008. Neraca Pembayaran Indonesia 2008 http://www.bi.go.id/id/publikasi/neracapembayaran/Pages/npi_trw408.aspx. [diakses pada 27 Februari 2016].

Bank Indonesia. 2009. Neraca Pembayaran Indonesia 2009. http://www.bi.go.id/id/publikasi/neracapembayaran/Pages/npi_tw409.aspx. [diakses pada 27 Februari 2016].

Bank Indonesia. 2010. Neraca Pembayaran Indonesia 2010 http://www.bi.go.id/id/publikasi/neracapembayaran/Documents/fdbbc92 2006e4a3fb1461fa9bd491760NPITwIV10 rev.pdf. [diakses pada 27 Februari 2016].

Bank Indonesia. 2012. Neraca Pembayaran Indonesia 2012 http://www.bi.go.id/id/publikasi/neracapembayaran/Documents/0dc0d2b 62c2f409aa88cf97029a46162LaporanNPITwIV2012r.pdf. [diakses pada 27 Februari 2016].

Febriyenti, Mega. Hasdi Aimon dan Zul Azhar. 2013. Faktor faktor yang Mempengaruhi Cadangan Devisa dan Net Ekspor di Indonesia. Kajian Ekonomi, 2(3): 156-171.

Hafizrianda, Y. 1998. Tingkat Instabilitas Ekspor Nonmigas Propinsi Irian Jaya. Bandung: Universitas Padjadjaran

Herrmann, Roland. 1983. The Effects of Partial International Price Stabilization on The Stability of National Export Earnings. Journal The Developing Economies. 208-224.

Jhingan, M. L. 2003. Ekonomi Pembangunan dan Perencanaan. Jakarta: PT RajaGrafindo Persada.

Kementerian Energi dan Sumber Daya Mineral. 2012. Kajian Kebijakan Pengembangan Industri Mineral sebagai Kawasan Ekonomi Khusus. http://prokum.esdm.go.id/Publikasi/Hasil\%20Kajian/ESDM \%20KEK.pdf. [diakses pada 24 Juli 2016].

Kementerian Energi dan Sumber Daya Mineral. 2012. Kajian Supply Demand Mineral. http://prokum.esdm.go.id/Publikasi/Hasil \%20Kajian/ESDM\%20SDM.pdf. [diakses pada 24 Juli 2016]. 
Kementerian Perdagangan. 2012. Memberdah Potensi Industri Perak Di Indonesia.

http://djpen.kemendag.go.id/app_frontend/admin/docs/publication/75813 60218691.pdf. [diakses pada 24 Juli 2016].

Mankiw, N. G. 2006. Makro Ekonomi. Jakarta: Erlangga.

Pan A., Yotopoulus dan Jeffrey B. Nuggent. 1976. Economics of
Development: Empirical Investigations. Singapore: Harper International Edition

Wong, C. M. 1986. Models Of Export Instability and Empirical Tests for Less-Developed Countries. Devdopment Economics, 20: 263-285 